The Geneva Papers on Risk and Insurance, 18 (No. 69, October 1993), 439-442

\title{
Consumers and Insurers - The Role of Insurance Supervision
}

\author{
by Dr. Knut Hohlfeld*
}

\section{The present system of insurance supervision in Europe}

Until now, insurance supervision in Europe has been characterised by a great variety of systems. In all countries State authorization is required to commence the transaction of insurance. Exceptions to this exist in some countries for the transaction of reinsurance. By contrast, on-going supervision is organized in very different ways. Here two basic models are to be distinguished. In some countries such as the U.K. and the Netherlands on-going supervision is in essence restricted to financial and solvency supervision. By contrast, the system in other countries - in particular Austria, Switzerland and Germany - is one of comprehensive material supervision by the State. In these countries product supervision supplements financial and solvency supervision. The insurance conditions and, in some cases, the premium rates of the insurance products being sold must be approved by the supervisory authority. Between these two distinct approaches there are numerous mixed forms in Europe, with a strong or less strong element of product supervision alongside the financial supervision.

\section{Forthcoming changes}

In 1992 EC Directives for Non-Life Insurance and for Life Insurance was promulgated, which will lead to a harmonisation of supervisory systems in the EC. This harmonisation is connected to far-reaching deregulation and liberalisation. The most important changes are the introduction of home country supervision and the ban on making the sale of insurance products conditional upon prior approval of insurance conditions or premium rates.

The introduction of home country supervision means that in future insurance companies will only be subject to supervision by the authority responsible for the country in which their headquarters are situated. Approval to transact insurance given by home country supervision will in future permit insurance to be transacted throughout the EC. Until now, approval was required by each country in which the company wished to conduct business.

* President of the Insurance Supervisory Office, Berlin. Paper presented at the Panel Discussion on the occasion of the General Assembly of the Geneva Association on the 7th June 1993 in Vienna. 
Prohibiting every form of prior approval of insurance conditions and premium rates does not, however, release companies from the duty of complying with the various laws of the EC's individual Member States. But in future the companies themselves will be responsible for checking the suitability of the products offered and the soundness of rating structures; their decisions are no longer dependent on the supervisory authority's approval.

In the area of financial supervision, the EC Directives provide for the possibility of a further liberalisation of Investment regulations. However, the Member States may still apply more exacting regulations to those insurance companies under the control of their own supervision

Furthermore, an important new duty of disclosure is to be introduced. The intention to acquire or dispose of a shareholding in an insurance company upwards of $10 \%$ of the voting rights or capital must be disclosed before being carried out. The supervisor will have the power to object to the intended acquisition, if he has doubts whether the purchaser will manage the insurance company in a sound and prudent way.

The EC Directives are to be incorporated into national law in time for their provisions to be effective from 1st July 1994 at the latest.

\section{Prognosis of the effects of deregulation}

The EC Directives' goal is to make the EC internal market reality in the insurance sector as well. Every insurance company should be allowed the freedom to devise its own products and sell them without hindrance in all the EC's Member States. Freedom for the companies to sell their products and freedom of choice for the customer are the fundamental principles of the deregulated insurance market.

The introduction of home country supervision makes matters considerably easier for the insurance companies. In all questions relating to their business activities in the whole of the EC they now need only communicate with one supervisory authority, namely that of their own country - and in their own language as well. However, the introduction of home country supervision creates certain difficulties for the insurance supervisory authorities. In future it will also have to monitor the overseas business conducted by the companies it supervises. This not only requires exact knowledge of the insurers' operations abroad, but also knowledge of the different legal systems in the EC Member States. So long as insurance contract law is not harmonised, this will, for the most part, place excessive demands on the supervisory authorities. For this reason, close cooperation between the supervisory authorities of the EC Member States will in future be indispensable. Cooperation, which is already very good, will become even closer. The preparation of guiding principles for the detailed regulation of this cooperation is already far advanced.

The removal of insurance conditions approval will lead to a greater variety of insurance products. However, present market transparency will suffer as a result. Prior approval of conditions did in fact guarantee clear language and standardised terminology. The more variety there is, the greater the danger of misleading products. The supervisory authority will normally only be able to detect unacceptable situations after they have occurred, in other words, after the customer has already suffered a loss. It will therefore become much more important than in the past for the buyer of insurance to obtain comprehensive professional advice from an insurance intermediary, before taking out an insurance policy. The EC Commission too has recognised how important good advice from an insurance inter- 
mediary is in a deregulated insurance market. It has therefore recommended the EC Member States to ensure that only qualified persons are permitted to become insurance intermediaries. In the interests of adequate consumer protection, I also believe this to be extremely necessary.

By abandoning approved tariffs, greater price competition and cheaper premiums for the consumer are expected. But this premium-based competition must not develop into ruinous price competition. The existing system of tariff approval in the insurance sector frequently failed to stop companies from considerably increasing premiums and failed to prevent cartels. The intention was more a matter of preventing excessive competition, which leads companies to reduce insurance premiums to such an extent that they are no longer in a position to meet their obligations in the event of a claim. On the other hand it is admitted that securing adequate premiums by means of approved tariffs can result in not all possibilities of cost reduction being taken.

In future too, insurance companies must at all costs be prevented from going into liquidation. For decades no German insurer has gone into liquidation. The one exception was the collapse of a small marine insurer, which could, however, be resolved without disadvantage to the consumer. The failure of a life assurance or health insurance company for example would have catastrophic consequences in Germany. One must take into consideration that on average the term of a life assurance policy in Germany is 30 years. If a life assurance company were to go into liquidation, the assureds' provisions for their retirement would collapse - perhaps after having paid in their premiums for over 20 years. In Germany the system of private health insurance is based on a continuous life-long contractual relationship with one insurer. For this reason, the insurer has no right of cancellation in normal circumstances. If a health insurer goes into liquidation, it will no longer be possible for the insured - unless he is young - to obtain health insurance cover with another health insurer at a premium he can afford.

After the abandonment of approved tariffs, financial supervision will assume much greater importance in preventing companies from failing than it does today. I am therefore concerned that only very limited use should be made of possibilities to liberalise financial supervision any further. Rigorous Investment regulations help prevent company failure and for this reason can be used as an effective publicity tool as well.

The requirement to give the supervisory authority prior notification of an intention to acquire or sell as shareholding is not without its dangers. Such notifications must remain strictly confidential. Otherwise the stock market would be endangered. Insider deals must be prevented at all costs.

\section{Conclusion}

From the middle of 1994 onwards, the insurance market will probably become more diverse and flexible in countries such as Germany in which insurance products were subject to a rigorous system of prior approval. It will become easier to introduce new products. Companies will be able to react more quickly to changes in consumer behaviour and market requirements.

Yet I also hope that this greater freedom will not be abused and that expectations will be fulfilled for a greater diversity of sensible and soundly priced insurance products, at premiums that are as low as possible. I would greatly welcome a situation where insurers continue to calculate their premium rates in a responsible manner and do not drive each 
other out of business. Of course wide ranging competition and great product diversity are the lifeblood of a functioning market economy. But increased competition also brings greater risks. Competition can reach a point at which the wider choice of products and lower premiums are offset by the risk of greater losses. It will be difficult to find and maintain the golden mean. Greater competition will also increase tendencies towards mergers and lead to a reduction in the number of competitors.

As the insurance supervisors in a system of material supervision by the State, as is the case in Germany, we will certainly lose some of our influence. The existing basis of prior approval of insurance products will be replaced by intervention after problems have come to light. But we will retain numerous important functions. Approval is still required to commence the transaction of insurance. We will in future not only monitor solvency but also the insurance companies' overall financial position. The duty to protect the insurance customer continues. The EC Directives clearly state that the duty of supervision remains to ensure that insurers stay within the law and to prevent situations which are to the customers' disadvantage or to remedy those that may occur. Thus the duties are the same, only the means of intervention will change. In any case I am sure that we will continue to have enough to do in the future.

In the meantime those countries who are not EC Members will have the opportunity of observing how deregulation affects the insurance sector. Depending on its successes or failures, they will be able to decide to what extent they wish to align their systems with the EC model. 